\title{
Is Macaronichnus an exclusively small, horizontal and unbranched structure? Macaronichnus segregatis degiberti isubsp. nov.
}

\author{
Francisco Javier RODRÍGUEZ-TOVAR* \& Julio AGUIRRE
}

Departamento de Estratigrafía y Paleontología, Facultad de Ciencias, Fuentenueva s/n Universidad de Granada, 18002 Granada, Spain; fjrtovar@ugr.es; jaguirre@ugr.es

* Corresponding author

Rodríguez-Tovar, F.J. \& Aguirre, J. 2014. Is Macaronichnus an exclusively small, horizontal and unbranched structure? Macaronichnus segregatis degiberti isubsp. nov. [¿Es Macaronichnus una estructura exclusivamente pequeña, horizontal y sin ramificar? Macaronichnus segregatis degiberti isubsp. nov.]. Spanish Journal of Palaeontology, 29 (2), 131-142.

Manuscript received 09 May 2013

Manuscript accepted 02 February 2014

(C) Sociedad Española de Paleontología ISSN 2255-0550

\begin{abstract}
The new ichnosubspecies Macaronichnus segregatis degiberti from Miocene deposits of Cádiz, SW Spain, is described. This ichnotaxa shows the characteristic presence of a mineralogical segregation within the tube, with a core made up of low density material, surrounded by a rim of glauconite. However, significant differences in size, orientation and branching with respect to the type species of Macaronichnus are observed. Macaronichnus segregatis degiberti is characterized by a diameter between $4 \mathrm{~mm}$ and $12 \mathrm{~mm}$, with common obliquely and even vertically oriented galeries, and the presence of frequent branching. Different types of branching can be observed, including false, primary/secondary successive, and true, simultaneous branchings. Specimens occur in a wide range of palaeoenvironmental contexts, from inner to outer sliciclastic shelf. This includes deeper and more distal habitats than those usually interpreted for Macaronichnus. Macaronichnus segregatis degiberti could be produced by a new tracemaker showing a composite behavior, pascichnia being the main strategy and dominichnia/cubichnia or repichnia, a secondary, sporadic one.
\end{abstract}

Keywords: Trace fossil, Macaronichnus, branching, palaeoecology, ethology, Miocene, SW Spain.

\section{RESUMEN}

Se describe la nueva icnosubespecie Macaronichnus segregatis degiberti en materiales del Mioceno de Cádiz, SO de España. Este icnotaxón posee la característica segregación mineralógica en el interior de la galería, con la presencia de una parte central compuesta por material de baja densidad, rodeada de un halo de glauconita. Sin embargo, se observan diferencias significativas en tamaño, orientación y ramificación respecto de la especie tipo de Macaronichnus. Macaronichnus segregatis degiberti se caracteriza por poseer un diámetro entre $4 \mathrm{~mm}$ y $12 \mathrm{~mm}$, frecuentes orientaciones oblicuas e incluso verticales, y la presencia de distintos tipos de ramificaciones, incluyendo falsas, sucesivas primarias/secundarias, y verdaderas, simultáneas. Se encuentran en un amplio rango paleoambiental, desde ambientes de plataforma interna proximal hasta plataforma externa, ambientes más profundos y distales que los usualmente interpretados para Macaronichnus. Macaronichnus segregatis degiberti podría haber sido producido por un nuevo organismo, mostrando un comportamiento compuesto, con una estrategia principal de alimentación y otra secundaria de domicilio/reposo o locomoción.

Palabras clave: Traza fósil, Macaronichnus, ramificación, paleoecología, etología, Mioceno, SO España. 


\section{INTRODUCTION}

Macaronichnus is a long-ranging ichnogenus recorded in fine- to medium-grained sandy marine deposits, mostly in high and intermediate latitudes, from Permian onwards (e.g., Clifton \& Thompson, 1978; Nara, 1994; Bromley, 1996; Pemberton et al., 2001, 2008; Gingras et al., 2002; Uchman \& Krenmayr, 2004; Bromley et al., 2009; Quiroz et al., 2010; Seike et al., 2011). It is interpreted as a feeding burrow, a grazing trace (pascichnia), produced by deposit-feeding worms, commonly in foreshore and shallow subtidal deposits (Clifton \& Thompson, 1978; Saunders \& Pemberton, 1986, 1990; Saunders, 1989; Pemberton et al., 2001, 2008). Similar feeding structures produced by the opheliid polychaetes Ophelia limacina (Clifton \& Thompson, 1978) and several species of the genus Euzonus (Pemberton et al., 2001; Gingras et al., 2002; Nara \& Seike, 2004; Seike, 2007, 2008, 2009; Dafoe et al., 2008a, b; Seike et al., 2011) have been observed in recent marine settings.

Since the original description by Clifton \& Thompson (1978) of Macaronichnus, the type ichnospecies Macaronichnus segregatis has been referred to an intrastratal preferentially horizontal trace, non-branching cylindrical structure, $3-5 \mathrm{~mm}$ in diameter. $M$. segregatis is characterized by the presence of a mineralogical segregation within the tube. Thus, the tube shows a core made up of low density material, light-colored felsic sand grains surrounded by a rim of high density material, and dark colored mafic sand grains.

Nonetheless, some morphological, compositional, and distributional variations have been recognized: 1) larger specimens (Curran, 1985; Masuda \& Yokokawa, 1988; Nara, 1998; Savrda \& Uddin, 2005; Aguirre et al., 2010; Seike et al., 2011); 2) obliquely and even vertically oriented traces (Pollard et al., 1993; Bann \& Fielding, 2004; Seike, 2007); 3) branched structures (Curran, 1985; Bann \& Fielding, 2004; Aguirre et al., 2010); 4) a diverse and complex range of burrow infill, including passive, active and meniscated (Bann \& Fielding, 2004); 5) latitudinal distribution, with frequent occurrences in tropical settings; and 6) deeper and comparatively more distal habitats, such as from inner and proximal middle shelf (Aguirre et al., 2010), some of them probably underestimated.

The upper Miocene-lower Pliocene deposits cropping out along the Atlantic coast of Cádiz, in the Conil-Cabo Roche area, are largely characterized by the pervasive occurrence of Macaronichnus segregatis. Aguirre et al. (2010) described a Macaronichnus ichnofabric dominated by $M$. segregatis as the most abundant ichnotaxa, followed by Bichodites monastiriensis, in the lower Pliocene sediments. These authors described $M$. segregatis as a large, unbranched burrow, and highlighted the presence of branched forms. In this paper, we analyze the morphological variations of Macaronichnus segregatis found in this area, a study initiated by Jordi M. de Gibert. Although Macaronichnus is pervasively present both in the Miocene and in the Pliocene sediments, we will focus on the upper Miocene deposits. Here, we confirm the presence of large, densely-packed traces of Macaronichnus, sometimes oblique and even vertical to the bedding plane, and often branched. Based on all these features, we propose a new ichnosubspecies, and discuss the potential implications for understanding the behavior and the ethological interpretation of the producer, as well as for palaeoecological approaches.

\section{GEOLOGICAL SETTING AND STRATIGRAPHY}

The study deposits crop out along the coastal cliffs NW of Conil de la Frontera (Cádiz, SW Spain), by the El Roqueo beach (Figs 1a-1b). This area lies at the southwestern margin of the Guadalquivir Basin, the foreland basin of the Betic Cordillera (Sanz de Galdeano \& Vera, 1992). The sedimentary infilling of this basin consists of Miocene to Pliocene marine deposits (Aguirre, 1995; Aguirre et al., 1995; Sierro et al., 1996; Braga et al., 2002; Martín et al., 2009). The studied deposits are late Tortonian-Messinian (Late Miocene) in age and they are exposed in a continuous succession, dipping $\sim 25^{\circ}$ to the southeast, that can be followed for hundreds of meters (Fig. 1b).

The stratigraphic section starts with silts and finegrained sands with intercalations of medium-grained sandstone beds. Nodular structures due to differential cementation occur in the silts. These deposits are enriched in glauconitic grains. Intervals of large scale trough-cross-bedding are present in this part of the section (Fig. 1c). Occasionally, the foreset beds of the sedimentary structures are slightly deformed. The massive sediments of this interval are pervasively bioturbated, thus disturbing the original sedimentary structures. Macaronichnus is the dominant trace fossil, followed by rare Bichordites.

In the middle part of the stratigraphic section, beds of marls are intercalated into the silts, thus changing gradually to an interval of massive bluish marls (Fig. 1c). Trace fossils are present in the lower part of this marly interval, where beds densely bioturbated by Macaronichnus alternate cyclically with massive, structureless beds.

Higher up in the section, grain size gradually increases, evolving to silts and finally fine-grained sands. Then, some packages of calcarenites, up to $4 \mathrm{~m}$ thick, intercalate the silts and sands (Fig. 1c). Calcarenites show trough-cross stratification. The thickness of these carbonate packages 

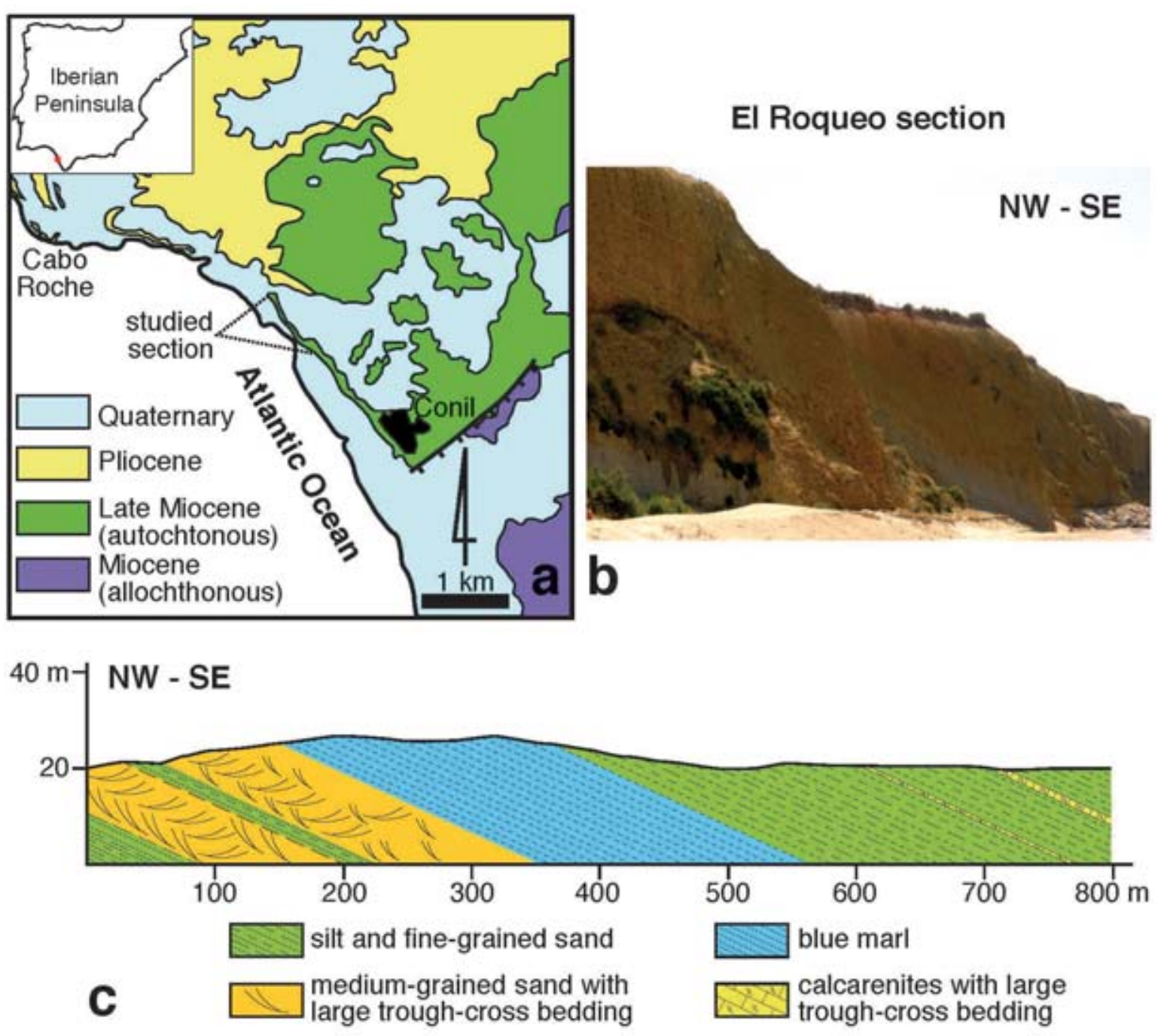

Figure 1. a) Geological map and the studied area. b) A panoramic view of the upper Miocene deposits along the El Roqueo beach. c) Diagramatic section of the studied deposits along El Roqueo.

increases higher up within the succession, although exposure is very poor.

The upper Miocene sequence ends with calcarenites and calcirudites showing trough-cross-bedding. These sediments are well exposed locally in Conil de la Frontera.

\section{MACARONICHNUS FROM MIOCENE DEPOSITS OF CÁDIZ, SW SPAIN}

\subsection{Taxonomic discussion}

The presence of a characteristic mantle concentration of glauconite and infilling with clean, non-glauconitic sand, either structureless or faintly backfilled, enables us to clearly assign the trace fossils to Macaronichnus. They differ from other morphologically similar non-meniscate ichnogenera, such as Planolites and Palaeophycus, as well as from meniscate ones, Muensteria, Anchorichnus and Scoyenia, as indicated by Saunders (1989). Differences between Planolites, Palaeophycus and Macaronichnus have been profusely analyzed (Clifton \& Thompson, 1978; Pemberton \& Frey, 1982; Fillion, 1989; Fillion \& Pickerill, 1990; Keighely \& Pickerill, 1995). Uchman \& Krenmayr (2004) indicated that when heavy minerals are scarce in the sediment, the characteristic segregation observed in Macaronichnus is poorly visible, and its separation from Planolites may be problematic.

Thus, most of the ichnological features of our specimens agree with those of the standard Macaronichnus, including the cylindrical shape, mineral segregation between the tube core and a surrounding rim, or dense distribution. However, several features of the studied Macaronichnus segregatis, 
such as size, orientation and branching, reveal significant differences with respect to the usually assigned forms of this ichnospecies.

\subsubsection{Size}

Most of Macaronichnus segregatis traces are (2)3-5 mm in diameter, which could be considered as the standard dimensions for this taxa. Only occasionally larger specimens, ranging from 5 to $15 \mathrm{~mm}$ in diameter, have been reported in Cretaceous (Curran, 1985; Pollard et al., 1993), Pliocene (Aguirre et al., 2010), and Pleistocene sediments (Masuda \& Yokokawa, 1988; Nara, 1998), as well as in Recent settings (Seike et al., 2011). Other larger Macaronichnus, 4-19 mm, described in Cretaceous sediments (Savrda \& Uddin, 2005) should be assigned to Bichordites on the basis of shape and internal structure (Seike et al., 2011) (see Uchman, 1995 for an emended diagnosis of Bichordites). In our study, Macaronichnus can be undoubtedly differentiated from the associated Bichordites monastiriensis (Aguirre et al., 2010). The latter consists of broad structures (4-14 cm wide) and horizontal, meniscate burrows, with a longitudinal median groove (Aguirre et al., 2010).

In our case, the size of $M$. segregatis ranges from $4 \mathrm{~mm}$ to $12 \mathrm{~mm}$ in diameter, with numerous specimens 7-9 $\mathrm{mm}$, and some structures larger than $20 \mathrm{~cm}$ long (Figs 2-5). This is clearly within the range of the larger Macaronichnus, very different from that of the type ichnospecies.

\subsubsection{Orientation}

Clifton \& Thompson (1978, p. 1293) indicated that Macaronichnus traces "tend to be preferentially oriented about a horizontal plane". Lately, some authors point out variations of this general pattern. Pollard et al. (1993; p. 154) recognized the presence of Macaronichnus tubes oblique to bedding in a particular OphiomorphaMacaronichnus ichnofabric. Uchman \& Krenmayr (2004, p. 238; text-fig. 19) stated that these traces are "mostly horizontal or sub-horizontal" but show abundant oblique forms in the illustrated examples of crosscutting relations. Bann \& Fielding (2004; fig. 16e) and Seike (2007; fig. 4) illustrated variable orientations with frequent oblique and vertical structures. Finally, Pervesler et al. (2011; p. 87-89) highlighted that they are "mostly horizontal and oblique". In the case study, horizontal forms are dominant, but oblique and vertical specimens are common (Fig. 2).

\subsubsection{Branching}

Together with the mineralogical segregation between the light-colored sand in the tube core and the dark-colored glauconite-rich sand in the surrounding mantle, the most distinctive feature of the ichnogenus Macaronichnus is the absence of real branching. In the original description of Macaronichnus segregatis, Clifton \& Thompson (1978; p. 1293) stressed, "the trails interpenetrate but do not branch, tend to be more or less horizontal, and generally occur in dense concentrations". Subsequently, Macaronichnus segregatis has been profusely studied, and some emended diagnoses have been presented. Nevertheless, it has mostly been considered as an unbranched burrow.

Four distinct modes of producing branching in biogenic structures have been described (D'Alessandro \& Bromley, 1987; Bromley, 1990, 1996): a) false, as an apparent branching originated by simple intersection and incomplete preservation, b) secondary successive, as a branched structure (false impression, not true) caused by two successive burrowers producing unbranched forms, when a tracemaker enters and follows an earlier, pre-existing burrow, and then deviates from it, c) primary successive, as a branched structure produced by an unbranched burrow through successive probing movements, and d) simultaneous, corresponding to networks where branches were simultaneously open. Of these four different types, the only one held to true branching is the simultaneous sort (Bromley, 1990, 1996).

It is evident that most of the illustrated branched $M$. segregatis, whether Recent or fossil counterparts, show a cross-cutting relationship, thus representing false branching due to intersections of different burrows (i.e., Fürsich, 1984; fig. 3b; Curran, 1985; plate 1B; Uchman \& Krenmayr, 2004; text-fig. 7B; Seike, 2007; figs. 3-4; Dafoe et al., 2008a, b; fig. 1A; Seike, 2009; fig. 6D; Quiroz et al., 2010; figs. 3B, C; Pervesler et al., 2011; fig. 2F; Seike et al., 2011; fig. 1A; among others). Presence of interpenetrating Macaronichnus is especially evident in the ichnospecies Macaronichnus simplicatus of Saunders (1989; fig. 27, plate 11; see also fig. 103 in Pemberton et al., 2001), and in the ichnosubspecies Macaronichnus segregatis spiriformis of Bromley et al. (2009). In other instances, however, specimens illustrated show branching structures that could not be definitively assigned to false branching, as in the papers by Curran (1985; plate 1C), MacEachern \& Pemberton (1992; fig.7b) and Bann \& Fielding (2004; figs. 6e and 7b).

In addition to the figured specimen, there are occasional references in the literature stressing that the observed branchings might not be true ramifications of the trace and could be due to cross-cuttings (e.g., Curran, 1985; Gingras et al., 2002; Uchman \& Krenmayr, 2004). Curran (1985) indicated that "burrows tend to be densely packed, and normally are unbranched, but branching can occur" (p. 263). He illustrated a branching form (Curran, 1985; plate 1C), and differentiated it from common burrow crossovers (Curran, 1985; plate 1B). Bromley (1990, 1996), however, indicated, "Curran (1985) identified a similar trace fossil as M. segregatis, but illustrated a Y-shaped 

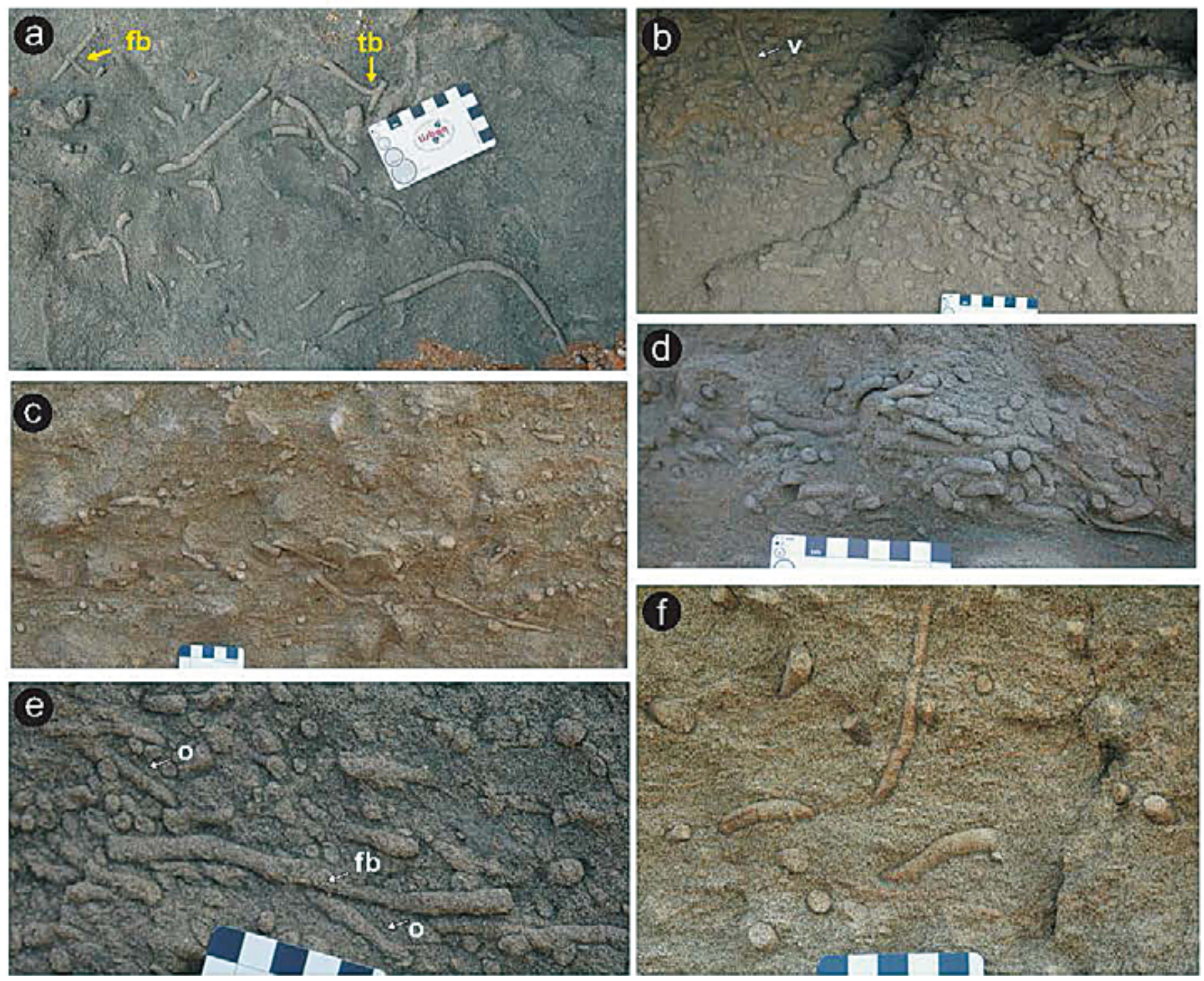

Figure 2. Outcrop views of Macaronichnus segregatis degiberti isubsp. nov. Rodríguez-Tovar \& Aguirre. a) Horizontal section showing straight and sinuous forms, as well as false ( $\mathrm{fb}$ ) and true (tb) branchings (see Fig. 5a for close-up view). b-f) Vertical sections. (b) Macaronichnus-bearing horizon with dominance of horizontal burrows and a nearly vertical (v) form, (c) dispersed Macaronichnus showing large horizontal forms, (d) high concentration of Macaronichnus showing intersections of burrows, (e) concentration of Macaronichnus with obliquely (o) oriented forms and false branching (fb), and (f) disperse Macaronichnus with vertical specimens. Note scale in centimeters to evidence large diameters of burrows.

simultaneous branching point. Thus, this structure cannot be considered trophically or ichnotaxonomically equivalent to $\mathrm{M}$. segregatis. In vertical section, and therefore in core, however, these structures would be indistinguishable. Branching is vitally important, but is not easy to see in vertical section" (Bromley, 1990; p. 179; Bromley, 1996; p. 204). In turn, Gingras et al. (2002), working on magnetic resonance images of recent Macaronichnus segregatis, indicated, "as noted from the hand sample, branching is not present. An exception to this may be imaged in Figure $3 E$, but the apparent branch there could also be explained as a composite of two out-of-plane burrows, which is expected inasmuch as each image slice represents a section of the medium approximately $0.5 \mathrm{~mm}$ thick. Plan-view images demonstrate more clearly the sinuous nature of the burrows (Fig. 4D, E; white arrows)" (Gingras et al., 2002; p. 553). Finally, Uchman \& Krenmayr (2004), studying monotypic ichnofabric formed by Macaronichnus, indicated that "the cross cuttings of Macaronichnus can give the impression of branches, but they are false branches sensu D'Alessandro \& Bromley (1987)" (Uchman \& Krenmayr, 2004; p. 245).

In our study, several types of branching were differentiated:

a) False branching is dominant, showing interpenetrating burrows in variable orientations, from perpendicular to near tangential (Fig. 3). 
b) Differentiation between secondary successive, primary successive and simultaneous is no easy matter, especially when the direction of the movement cannot be approached due to the absence of meniscus orientation. In secondary successive branching, the organism reworks the backfill of the pre-existing burrow and, in many cases, the movement is opposite in the two burrows. When movements are concordant, however, it is difficult to distinguish this style from the primary successive (D’Alessandro \& Bromley, 1987). Primary successive
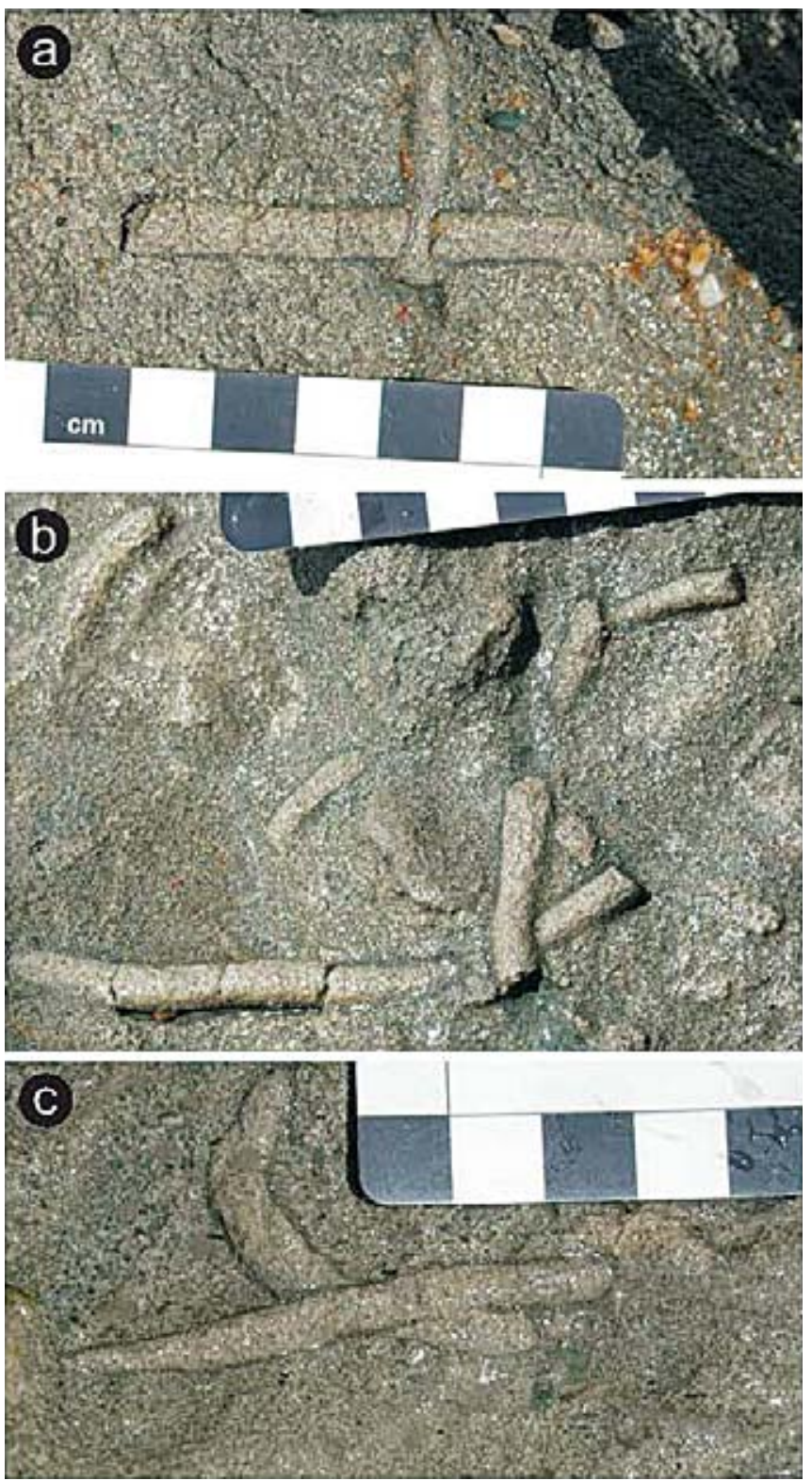

Figure 3. False branching of Macaronichnus segregatis degiberti isubsp. nov. Rodríguez-Tovar \& Aguirre, with examples of perpendicular (a), oblique (b) and near tangential (c) intersections. Note green halo to evidence the cross-cutting relationships. Scale is in centimeters to evidence large diameters of burrows. shows a characteristic backfilling, and in the simultaneous branching, the true branching, the fill must be emplaced by different means and a characteristic meniscus orientation cannot be defined (D'Alessandro \& Bromley, 1987; Bromley, 1990, 1996). In the studied Macaronichnus, the absence of meniscate structures excludes the use of this feature for distinguishing among the different branching patterns. Therefore, other features must be considered. Apart from the meniscus orientation, both secondary successive and primary successive styles show a clear differentiation between the burrow walls corresponding to the two different burrows in the case of the secondary successive style, or to the burrows corresponding to the several probes originated by the same animal in the case of the primary successive style. In the study case, different burrow walls in a unique structure have been occasionally recognized, proving the existence of primary and/or secondary branching. The absence of meniscus precludes any definitive differentiation between the two types; yet the presence of only one branch, not several probes, could be indicative of secondary successive branching (Fig. 4).

c) Apart from the aforementioned types of branching, in several cases the observed branched forms do not display different burrow mantles associated to primary or secondary branching, but rather a clear continuity in the burrow infill in the entire structure (from the main burrow to the branch) (Fig. 5). A single branch is usually recognized in the branching structure, but occasionally several small branches have been observed in the same structure (Figs 5d-5f). In these cases two possibilities could be considered: i) a true, simultaneous branching, and ii) a secondary successive branching without burrow mantle in the intersection of the corresponding two different burrows. In this second possibility, the worm ingests in a pre-existing Macaronichnus burrow in which the infilling material have not mafic grains because they constitute the mantle of the previous burrow (Seike, per. com.). Thus, dark colored mantle is not produced at the intersection of the two burrows. The use of a pre-existing Macaronichnus burrow would reflect; either a re-exploitation by the tracemaker for food of the infilling material (pascichnia behavior) in a material previously ingested and then with lower organic matter content, that appears profitableness, or a locomotion trace. This latter alternative involves a change of the tracemaker behavior from pascichnia to repichnia. 

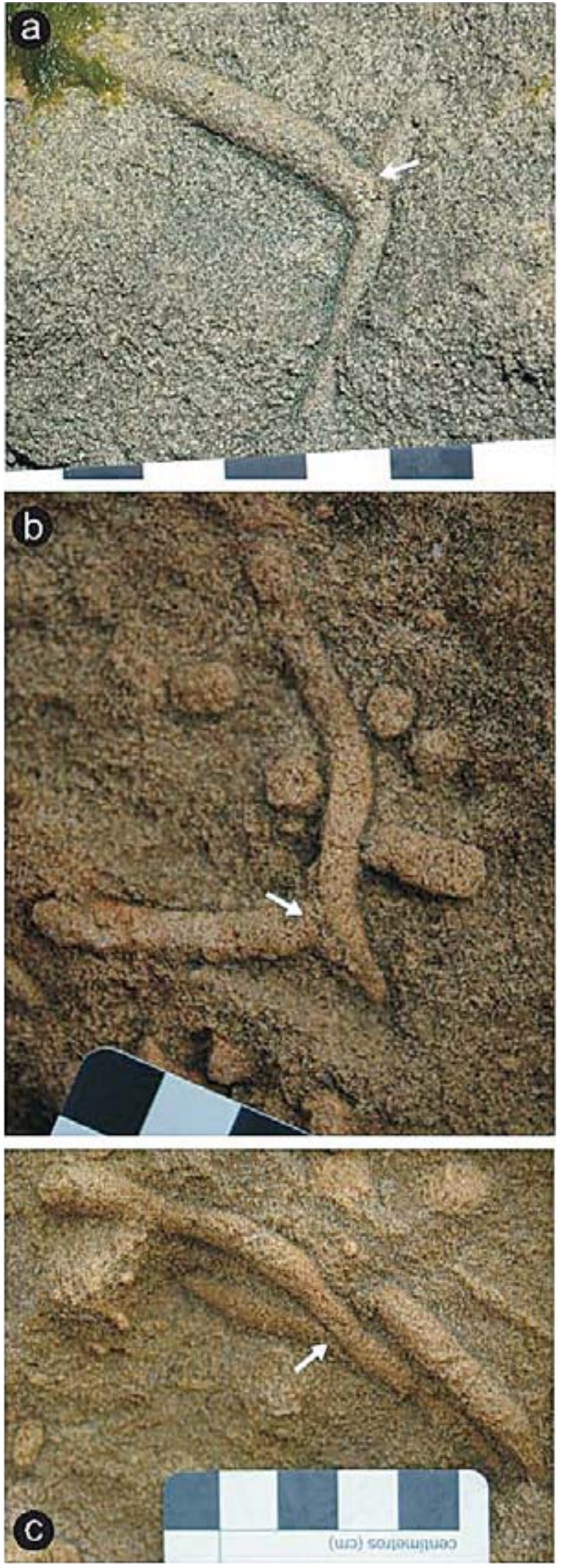

Figure 4. Secondary successive branching in Macaronichnus segregatis degiberti isubsp. nov. Rodríguez-Tovar \& Aguirre. Note variability in the angle of branching, and differentiation (cross-cutting relationships) of burrow walls with the characteristic mantle concentration of green glauconite (white arrows).

\section{MACARONICHNUS SEGREGATIS DEGIBERTI ISUBSP. NOV.}

Since the original designation of Macaronichnus segregatis by Clifton \& Thompson (1978), the ichnotaxonomical subdivision of Macaronichnus has scarcely been approached. Several emendations and new diagnoses have been proposed (Saunders, 1989; Saunders \& Pemberton, 1990; Bromley et al., 2009). Moreover, ichnotaxonomical descriptions have been confusing in some cases. Thus, for example, Saunders (1989; fig. 27) figured an exemplar of Macaronichnus simplicatus that was later referred to as Planolites sp. in fig. 1 by Saunders \& Pemberton (1990; text-fig. 13), and finally illustrated again as Macaronichnus simplicatus by Pemberton et al. (2001; fig. 103).

In his M.Sc. thesis, Saunders (1989) revised the ichnogenus Macaronichnus, and included an emended diagnosis, recognizing three distinct forms of Macaronichnus based on the foraging pathway configurations (fig. 27 in Saunders, 1989; see also fig. 103 in Pemberton et al., 2001). He distinguished two ichnospecies, Macaronichnus segregatis, with two varieties or ichnosubspecies named M. segregatis segregatis and M. segregatis spiralis, and $M$. simplicatus. M. segregatis segregatis is characterized by random burrows but with no interpenetration structures. $M$. segregatis spiralis shows distinct planispiral arrangement configurations. Finally, the ichnospecies Macaronichnus simplicatus is characterized by random interpenetrating burrows. This subdivision has been subsequently used by several authors (e.g., Pemberton, 1992; Pemberton et al., 2001; Bann \& Fielding, 2004; Bann et al., 2004; Gordon et al., 2010).

In a new reassessment of the ichnogenus Macaronichnus, Saunders \& Pemberton (1990) changed the status of the two ichnosubspecies described by Saunders (1989) to species level. Thus, they proposed the ichnospecies $M$. segregatis, which corresponds with the definition of $M$. segregatis segregatis of Saunders (1989), and the new ichnoespecies M. spiralis, corresponding to the ichnosubspecies variety of M. segregatis spiralis in Saunders (1989). However, no reference to this change in the taxonomical assignation is presented by Saunders \& Pemberton (1990).

Bromley et al. (2009) made another detailed revision of Macaronichnus, providing a new diagnosis for the type ichnospecies $M$. segregatis, and described three new ichnosubspecies, M. segregatis lineiformis, M. segregatis spiriformis and M. segregatis maeadriformis. These three new ichnotaxa are described at ichnosubspecies rank on the basis of the different degrees of spirality and meandering. These morphotypes of $M$. segregatis probably represent foraging optimization under different regimes of porewater movement, even other hypothesis has been proposed; Seike (2008) interpreted that the tracemaker also modified behavioral patterns in response to the beach topographical changes due to wave conditions. With the designation of 

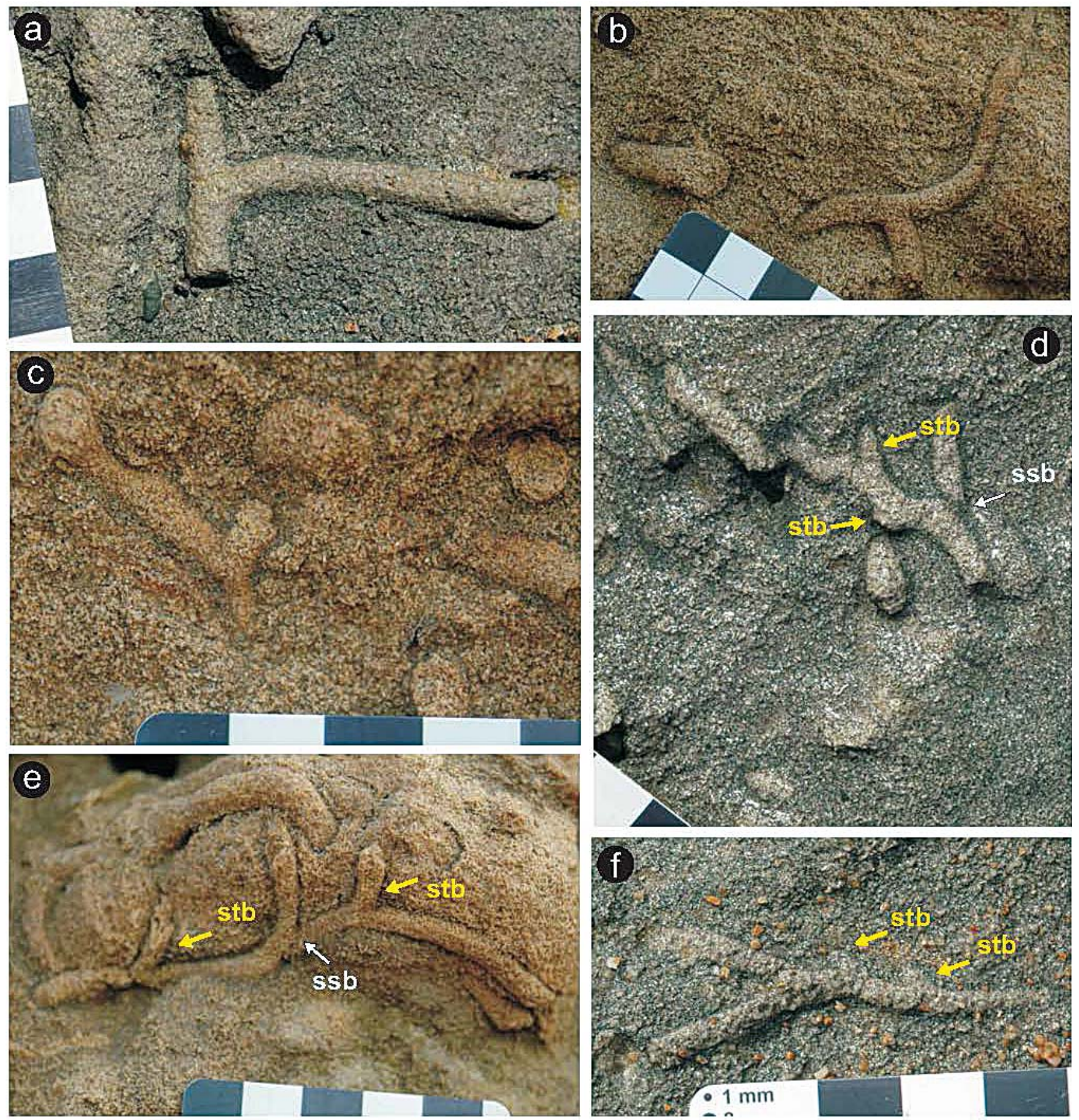

Figure 5. True branching in Macaronichnus segregatis degiberti isubsp. nov. Rodríguez-Tovar \& Aguirre. a, b, c) Specimens showing variability in the angle of true branching or of secondary successive branching without mantle differentiation, and in the length of branches. Note the absence of differentiation of burrow mantle, and the characteristic mantle concentration of branching. d, e, f) Specimens showing secondary successive branching (ssb, white arrows) and small true branches (stb, yellow arrows) in the same structure.

these three new ichnosubspecies, Bromley et al. (2009) considered the originally described $M$. segregatis by Clifton \& Thompson (1978) as another ichnosubspecies, $M$. segregatis segregatis. Bromley and coauthors considered that the three morphological varieties represent different ichnosubspecies, because they share the core-and-mantle organization that characterizes $M$. segregatis. In addition, Bromley et al. (2009, p. 117) stated that the ichnospecies Macaronichnus spiralis distinguished by Saunders \& Pemberton (1986) (see Saunders \& Pemberton, 1990; fig. 1, and MacEachern \& Pemberton, 1992; fig. 6D) must be considered a nomen nudum because it was described in 
field guidebooks that cannot be recognized as publications according with the ICZN (1999), and thus the name remains informal.

Seike et al. (2011) emphasized the importance of the size of Macaronichnus (small and large burrows) for reconstructing detailed palaeoenvironments. However, they did not distinguish any new taxa for the large presentday Macaronichnus isp. produced by Travisia japonica, because according to Bertling et al. (2006) the size of the traces is not a valid characteristic in ichnotaxonomy.

Clifton \& Thompson (1978; p. 1295), when describing the trace fossil Macaronichnus segregatis n. ichnogen., $\mathrm{n}$. ichnosp., indicated that the "generic term Macaronichnus is from the Italian "maccaroni" and refers to the size and shape. The trivial term segregatis, from the Latin "segregare", refers to the fact that "the trail is defined by mineralogic segregation within the host sand". Accordingly, we consider that the morphological differences in the studied Macaronichnus - the large size, the diverse orientation, and the conspicuous branching patterncould be significant for the definition of a new species of Macaronichnus. Nonetheless, taking into account that mineralogic segregation is recognized as a major feature of the type ichnospecies, we consider the designation of a new ichnosubspecies within Macaronichnus segregatis.

\section{Macaronichnus segregatis degiberti isubsp. nov. Rodríguez-Tovar \& Aguirre}

(Figs 2-4)

Diagnosis. Large Macaronichnus segregatis (4-12 mm in diameter) with occasional true branching and locally showing obliquely to vertically oriented galeries with respect to bedding.

Deriviation of name. In honor of Jordi Maria de Gibert, 2012, a well-known and widely reputed Spanish palaeoichnologist who first dealt with the problem of branching in Macaronichnus from the studied area.

Description. Macaronichnus segregatis degiberti is characterized by a larger diameter $(4-12 \mathrm{~mm}$ in diameter, with common structures in the range of 7-9 $\mathrm{mm}$, and occasionally longer than $20 \mathrm{~cm}$ ) than the standard Macaronichnus segregatis (3-5 $\mathrm{mm}$ in diameter). True branching is often observed. This ichnosubspecies is mostly horizontally arranged, with the tubes parallel to bedding. However, obliquely and vertically oriented traces can be sometimes recognized.

Syntypes. Since Macaronichnus segregatis degiberti isubsp. nov. Rodríguez-Tovar \& Aguirre consists of specimens with variable distinctive features, such as different size, and horizontal to vertical, unbranched and branched forms, we cannot differentiate a single specimen (holotype) as the name-bearing type. All the characteristic features for identifying the ichnotaxon are observable in the type locality; that is, the upper Miocene deposits cropping out along the sea cliffs of El Roqueo, NW of Conil de la Frontera (Fig. 1). According to the ICZN 1999 (Art.73.2), we consider as the most appropriate strategy to define Macaronichnus segregatis degiberti isubsp. nov. Rodríguez-Tovar \& Aguirre would be the use of syntypes in reference to all specimens of the type series that collectively constitute the name-bearing type. Selected syntypes are housed at the Department of Stratigraphy and Palaeontology, University of Granada, Spain, under the general label ROQ.

Type horizon and locality. Miocene deposits cropping out along the cliffs between Conil and the Cabo Roche area, along the Atlantic coast of Cádiz (Fig. 1).

Discussion. The presence of the characteristic halo and the difference between the filling material and the host sediment support assignment to Macaronichnus segregatis in view of other morphologically similar meniscate and non-meniscate structures. Larger size, common oblique and even vertical orientation, and presence of true branching, not discarding a secondary successive branching without dark mantle in the intersection of the corresponding two different burrows, allow for differentiation from the standard Macaronichnus segregatis.

\section{PALAEOBIOLOGICAL AND PALAEOECOLOGICAL IMPLICATIONS}

The palaeoecological and paleoenvironmental significance of Macaronichnus segregatis may be an indicator of ancient sea level, shoreline orientation, and beach morphodynamics (Nara, 1998; Nara \& Seike, 2004; Seike, 2007, 2008, 2009, and references therein). Nonetheless, Bromley et al. (2009) underline that the literature dealing with the environmental range of Macaronichnus is confusing.

Quiroz et al. (2010) have recently suggested that this trace fossil is typically associated with upwelling conditions in tropical settings that causes strong seasonality of cold waters and replenishes the surface waters with nutrients. The ichnospecies and ichnosubspecies of Macaronichnus proposed by Saunders (1989) -Macaronichnus simplicatus, M. segregatis segregatis and M. segregatis spiralis - were interpreted to be related to increasing foraging optimizations (fig. 27 in Saunders, 1989). The three ichnosubspecies of Bromley et al. (2009) - M. segregatis lineiformis, M. segregatis meandriformis, and $M$. segregatis spiriformis - were contrastively interpreted to be linked to different pore-water flow related 
to seasonal (winter and summer) conditions (fig. 15 in Bromley et al., 2009).

Furthermore, based on the distribution of the modern Euzonus worm (a possible producer of Macaronichnus trace fossils), two aspects have been addressed: a) the variation of burrowing behavior of the tracemaker in response to the magnitude of beach topographical changes due to wave conditions (Seike, 2008), and b) the relationship between the vertical thickness of Macaronichnus segregatis-bearing beds and the ancient beach morphodynamics; a greater bed thickness being associated with decreasing beach-face gradient (Seike, 2009).

As indicated by Seike et al. (2011), the differentiation of large Macaronichnus has significant palaeoenvironmental implications. According to the distribution of the different producers (Ophelia limacina, Euzonus spp, and Travisia spp) recognized in modern settings, ecological and depositional differences can be envisaged. Thus, the standard (small) M. segregatis is commonly related to high energy environments in foreshore and shallow subtidal settings, while large Macaronichnus could be associated with a wider range of depositional environments and bathymetry, including tidal flats, upper-lower shoreface, continental shelf, and possibly even deep-sea floor (Seike et al., 2011).

In the context of our study, significant differences can be surmised in the palaeoenvironment with respect to that usually interpreted for Macaronichnus. As occurs for the Macaronichnus assemblages previously described in Pliocene deposits (Aguirre et al., 2010), the studied succession represents middle to outer shelf environments. Hence the habitat of Macaronichnus tracemaker must be extended to deeper and comparatively more distal areas than those usually proposed for this trace. Two possible interpretations are proposed: a) a different distribution of the producers of Macaronichnus (Ophelia limacina, Euzonus spp, and Travisia spp) during Pliocene and Miocene times; and b) different Macaronichnus tracemakers than those proposed, adapted to the ecological and depositional conditions typical of deeper and more distal environments.

In short, Macaronichnus represents the activity of deposit-feeder worms in well-oxygenated sediments, at a depth usually below $20 \mathrm{~cm}$ from the water-sediment interface, allowing a deep-tier position (Saunders \& Pemberton, 1986; Pemberton et al., 2001; Bann and Fielding, 2004; Bromley et al., 2009).

An important unresolved question resides in the presence of true branching in structures associated with pascichnia behavior. As indicated by Bromley (1996; p. 202), "repichnia and pascichnia cannot truly be branched". Nevertheless, it has indeed been recognized on occasion, as in the well-known Planolites, interpreted as pascichnion and referred to polyphyletic vermiform deposit-feeders producing active backfilling, which is rarely branched
(Pemberton \& Frey, 1982; Fillion \& Pickerill, 1990; Uchman, 1995; Stanley \& Pickerill, 1998). A possible interpretation is that these short branches represent semipermanent domiciles (domichnia behavior) or even resting traces (cubichnia) during continuous feeding locomotion. In this event, the presence of small true branches (Figs 5d-5f) in Macaronichnus segregatis degiberti could reveal a composite behavior, pascichnia being the main strategy, together with dominichnia/cubichnia as a secondary, sporadic one. Accordingly, any of the traditionally assigned producers of short and large Macaronichnus must be discarded, and a new tracemaker, with a new behavior, must be considered. As indicated above, Bann \& Fielding (2004) observed structures assigned to Macaronichnus isp. with branches and containing a diverse and complex range of burrow infill. The authors interpreted these features as representing different components of the same biogenic structure. For these authors, those parts of the burrow passively infilled appear to have been lined and then remained open, while the ones actively filled represent backfilled or waste-stuffed chambers. This interpretation is significantly different from the traditional proposals, and, as we propose, supports a complex and variable behavior of the tracemakers. In case that these branches were considered as secondary successive branching without dark mantle, the re-exploitation for food of a previously ingested material could be interpreted as revealing a change of the behavior tracemaker from pacichnia to a probably repichnia.

\section{ACKNOWLEDGMENTS}

We sincerely acknowledge the reviewer Koji Seike and the guest editor A. A. Ekdale, for their suggestions and comments that have improved the quality of the paper. Research by R.-T. was supported by Projects CGL200803007 and CGL2012-33281 (Secretaría de Estado de I+D+I, Spain), Project RNM-3715 and Research Group RNM-178 (Junta de Andalucía). The work of J.A. was supported by research project CGL2010-20857 (Secretaría de Estado de I+D+I, Spain), and the research group RNM190 (Junta de Andalucía). We thank Alfred Uchman for his help with the ichnotaxonomical nomenclature.

\section{REFERENCES}

Aguirre, J. 1995. Implicaciones paleoambientales y paleogeográficas de dos discontinuidades estratigráficas en los depósitos pliocénicos de Cádiz (SW de España). Revista de la Sociedad Geológica de España, 8, 161-174. 
Aguirre, J., Castillo, C., Férriz, F.J., Agustí, J. \& Oms, O. 1995. Marine-continental magnetobiostratigraphic correlation of the Dolomys subzone (middle of Late Ruscinian): implications for the Late Ruscinian age. Palaeogeography, Palaeoclimatology, Palaeoecology, 117, 139-152.

Aguirre, J., de Gibert, J.M. \& Puga-Bernabéu, A. 2010. Proximal-distal ichnofabric changes in a siliciclastic shelf, Early Pliocene, Guadalquivir Basin, southwest Spain. Palaeogeography, Palaeoclimatology, Palaeoecology, 291, 328-337.

Bann, K. \& Fielding, C.R. 2004. An integrated ichnological and sedimentological comparison of non-deltaic shoreface and subaqueous delta deposits in Permian reservoir units of Australia. In: The application of ichnology to palaeoenvironmental and stratigraphic analysis (ed. McIlroy, D.). The Geological Society of London, Special Publication, 228, 273-310.

Bann, K., Fielding, C.R., MacEachern, J.A. \& Tye, S.C. 2004. Differentiation of estuarine and offshore marine deposits using integrated ichnology and sedimentology: Permian Pebbly Beach Formation, Sydney Basin, Australia. In: The application of ichnology to palaeoenvironmental and stratigraphic analysis (ed. McIlroy, D.). The Geological Society of London, Special Publication, 228, 179-210.

Bertling, M., Braddy, S.J., Bromley, R.G., Demathieu, G.R., Genise, J., Mikuláš, R., Nielsen, J.K., Nielsen, S.S., Rindsberg, A.K., Schlirf, M. \& Uchman, A. 2006. Names for trace fossils: a uniform approach. Lethaia, 39, 265-286.

Braga, J.C., Martín, J.M. \& Aguirre, J. 2002. Tertiary. Southern Spain. In: The Geology of Spain (eds Gibbons, W. \& Moreno, T.). The Geological Society, London, 320-327.

Bromley, R.G. 1990. Trace fossils: biology and taphonomy. Unwin Hyman, London.

Bromley, R.G. 1996. Trace Fossils - Biology, Taphonomy and Applications. Chapman \& Hall, London.

Bromley, R.G., Uchman, A., Milàn, J. \& Hansen, K. 2009. Rheotactic Macaronichnus, and human and cattle trackways in Holocene beachrock, Greece: reconstruction of paleoshoreline orientation. Ichnos, 16, 103-117.

Clifton, H.E. \& Thompson, J.K. 1978. Macaronichnus segregatis: a feeding structure of shallow marine polychaetes. Journal of Sedimentary Petrology, 48, 1293-1302.

Curran, H.A. 1985. The trace fossil assemblage of a Cretaceous nearshore environment: Englishtown Formation of Delaware, U.S.A. In: Biogenic structures: their use in interpreting depositional environments (ed. Curran, H.A.). Society for Economic Paleontologists and Mineralogists, Special Publication, 35, 261-276.

Dafoe, L.T., Gingras, M.K. \& Pemberton, S.G. 2008 a. Determinating Euzonus mucronata burrowing rates with application to ancient Macaronichnus segregatis tracemakers. Ichnos, 15, 78-90.

Dafoe, L.T., Gingras, M.K. \& Pemberton, S.G. 2008b. Analysis of mineral segregation in Euzonus mucronata burrow structures: one possible method in the construction of ancient Macaronichnus segregates. Ichnos, 15, 91-102.

D’Alessandro, A. \& Bromley, R.G. 1987. Meniscate trace fossils and the Muensteria-Taenidium problem. Palaeontology, 30, 743-763.

Fillion, D. 1989. Les critères discriminants à l'intérieur du triptyque Palaeophycus-Planolites-Macaronichnus. Essai de synthése d'un usage critique. Comptes Rendus de l'Académie des Sciences de Paris, 309, 169-172.

Fillion, D. \& Pickerill, R.K. 1990. Ichnology of the Upper Cambrian? to Lower Ordovician Bell Island and Wabana groups of eastern Newfoundland, Canada. Palaeontographica Canadiana, 7, 1-119.

Fürsich, F.T. 1984. Palaeoecology of boreal invertebrate faunas from the Upper Jurassic of Central East Greenland. Palaeogeography, Palaeoclimatology, Palaeoecology, 48, 309-364.

Gingras, M.K., MacMillan, B., Balcom, B.J., Saunders, T. \& Pemberton, S.G. 2002. Using magnetic resonance imaging and petrographic techniques to understand the textural attributes and porosity distribution in Macaronichnusburrowed sandstone. Journal of Sedimentary Research, 72, 552-558.

Gordon, J.B., Pemberton, G., Gingras, K. \& Kohauser, K.O. 2010. Biogenically enhanced permeability: A petrographic analysis of Macaronichnus segregatus in the Lower Cretaceous Bluesky Formation, Alberta, Canada. AAPG Bulletin, 94, 1779-1795.

ICZN (International Commission for Zoological Nomenclature) 1999. International Code of Zoological Nomenclature, adopted by the International Union of Biological Sciences, 4th ed. International Trust for Zoological Nomenclature, London.

Keighley, D.G. \& Pickerill, R.K. 1995. The ichnotaxa Palaeophycus and Planolites: historical perspectives and recommendations. Ichnos, 3, 301-309.

Masuda, F. \& Yokokawa, M. 1988. Pleistocene beach deposits in Tsukuba Upland. Tsukuba Environmental Studies, 11, 113-122 (In Japanese with English abstract).

MacEachern, J.A. \& Pemberton, S.G. 1992. Ichnological aspects of Cretaceous shoreface succession and shoreface variability in the Western Interior seaway of North America. In: Application of ichnology to petroleum exploration. A core workshop (ed. Pemberton, S.G.). Society of Economic Paleontologists and Mineralogists, Core Workshop, 17, 57-84.

Martín, J.M., Braga, J.C., Aguirre, J. \& Puga-Bernabéu, A. 2009. History and evolution of the North-Betic Strait (Prebetic Zone, Betic Cordillera): A narrow, early Tortonian, tidal-dominated, Atlantic-Mediterranean marine passage. Sedimentary Geology, 216, 80-90.

Nara, M. 1994. What is the producer of "trace fossil of Excirolana chiltoni”? - Tracemaking mechanism of Macaronichnus segregatis. Fossils, 56, 9-20 (In Japanese with English abstract).

Nara, M. 1998. Depositional environments and sequence stratigraphic analysis of the Middle Pleistocene Kongochi 
Formation. Journal of Geography, 107, 77-91 (In Japanese with English abstract).

Nara, M. \& Seike, K. 2004. Macaronichnus segregatislike traces found in the modern foreshore sediments of the Kujukurihama Coast, Japan. Journal of Geological Society of Japan, 110, 545-551 (In Japanese with English abstract).

Pemberton, G.S. \& Frey, R.W. 1982. Trace fossil nomenclature and the Planolites-Palaeophycus dilemma. Journal of Paleontology, 56, 843-881.

Pemberton, S.G. (ed.) 1992. Applications of Ichnology to Petroleum Exploration. A Core Workshop. SEPM Core Workshop, 17.

Pemberton, S.G., Spila, M., Pulham, A.J., Saunders, T., MacEachern, J.A., Robbins, J. \& Sinclair, I.K. 2001. Ichnology and sedimentology of shallow marginal marine systems. Geological Association of Canada. Short Course Notes, 15.

Pemberton, S.G., MacEachern, J.A., Gingras, M.K. \& Saunders, T.D.A. 2008. Biogenic chaos: Cryptobioturbation and the work of sedimentologically friendly organisms: Palaeogeography, Palaeoclimatology, Palaeoecology, 270, 273-279.

Pervesler, P., Uchman, A., Hohenegger, J. \& Dominici, S. 2011. Ichnological record of environmental changes in Early Quaternary (Gelasian-Calabrian) marine deposits of the Stirone section, northern Italy. Palaios, 26, 578-593.

Pollard, J. E., Goldring, R., \& Buck, S. G. 1993. Ichnofabrics containing Ophiomorpha: significance in shallow-water facies interpretation. Journal of the Geological Society, London, 150, 149-164.

Quiroz, L.I., Buatois, L.A., Mángano, M.G., Jaramillo, C.A. \& Santiago, N. 2010. Is the trace fossil Macaronichnus segregatis an indicator of temperate to cold waters? Exploring the paradox of its occurrence in tropical coasts. Geology, 38, 651-654.

Sanz de Galdeano, C. \& Vera, J.A., 1992. Stratigraphic record and palaeogeographical context of the Neogene basins in the Betic Cordillera, Spain. Basin Research, 4, 21-36.

Saunders, T.D.A. 1989. Trace fossils and sedimentology of a Late Cretaceous progradational barrier island sequence: Bearpaw-Horseshoe Canyon Formation transition, Dorothy, Alberta. M.Sc. Thesis, University of Alberta.

Saunders, T.D.A. \& Pemberton, S.G. 1986. Trace fossils and sedimentology of the Appaloosa Sandstone: BearpawHorseshoe Canyon Formation transition, Dorothy,
Alberta. Canadian Society of Petroleum Geologists, Field Trip Guide Book.

Saunders, T.D.A. \& Pemberton, S.G. 1990. Trace fossils and sedimentology of the Appaloosa sandstone: BearpawHorseshoe canyon formations transition, Dorothy, Alberta. Edmonton Geological Society field trip guidebook.

Savrda, C.E. \& Uddin, A. 2005. Large Macaronichnus and their behavioral implications (Cretaceous Eutaw Formation, Alabama, USA). Ichnos, 12, 1-9.

Seike, K. 2007. Palaeoenvironmental and palaeogeographical implications of modern Macaronichnus segregates-like traces in foreshore sediments on the Pacific coast of Central Japan. Palaeogeography, Palaeoclimatology, Palaeoecology, 252, 497-502.

Seike, K. 2008. Burrowing behaviour inferred from feeding traces of the opheliid polychaete Euzonus sp. as response to beach morphodynamics. Marine Biology, 153, 11991206.

Seike, K. 2009. Influence of beach morphodynamics on the distributions of the opheliid polychaete Euzonus sp. and its feeding burrows on a sandy beach: paleoecological and paleoenvironmental implications for the trace fossil Macaronichnus segregatis. Palaios, 24, 799-808.

Seike, K., Yanagishima, S., Nara, M. \& Sasaki, T. 2011. Large Macaronichnus in modern shoreface sediments: Identification of the producer, the mode of formation, and paleoenvironmental implications. Palaeogeography, Palaeoclimatology, Palaeoecology, 311, 224-229.

Sierro, F.J., González-Delgado, J.A., Dabrio, C.J., Flores, J.A. \& Civis, J. 1996. Late Neogene depositional sequences in the foreland basin of Guadalquivir (SW Spain). In: Tertiary Basins of Spain (eds Friend, P. \& Dabrio, C.J.). Cambridge University Press, 339-345.

Stanley, D.C.A. \& Pickerill, R.K. 1998. Systematic ichnology of the Late Ordovician Georgian Bay Formation of southern Ontario. Royal Ontario Museum, Life Sciences Contributions, 162, 1-56.

Uchman, A. 1995. Taxonomy and palaeoecology of flysch trace fossils: The Marnoso-arenacea Formation and associated facies (Miocene, Northern Apennines, Italy). Beringeria, 15, 3-115.

Uchman, A. \& Krenmayr, H.G., 2004. Trace fossils, ichnofabrics and sedimentary facies in the shallow marine Lower Miocene Molasse of upper Austria. Jahrbuch der Geologischen Bundesantalt, 144, 233-251. 